\title{
PENERAPAN METODE PERSEDIAAN DALAM PERENCANAAN PAJAK
}

\author{
Sri Sunarni Sonu ${ }^{1}$, Novi Swandari Budiarso ${ }^{2}$ \\ ${ }^{1}$ PDAM Duasudara, Jl. Depot Pertamina, Bitung Tengah, Maesa, Kota Bitung, Sulawesi Utara, Indonesia \\ ${ }^{2}$ Program Studi Pendidikan Profesi Akuntansi, Fakultas Ekonomi dan Bisnis, Universitas Sam Ratulangi, Jl. \\ Kampus Bahu, Manado, 95115, Indonesia \\ Email: srisunarnisonu@gmail.com
}

\begin{abstract}
Inventories are generally owned and used by companies for sale, for normal business operations, or for goods that are to be used or consumed in making goods for sale. There are two methods that can be used by taxpayers in assessing inventory and using inventory to calculate the cost of goods sold namely the first in first out method and the average method. The use of the FIFO method will result in a smaller cost of goods sold than the Average method so that the company's net income will be greater and the tax burden that must be borne by taxpayers is also greater. While the use of the Average method will result in a smaller profit margin so that for tax burden efficiency it is more effective to use the average method than the FIFO method. In other words, the smaller the profit margin obtained, the smaller the amount of tax burden that must be paid.
\end{abstract}

Keywords: average; FIFO; inventories; tax planning

\section{PENDAHULUAN}

Pajak merupakan sumber pendapatan bagi negara yang diatur dengan UndangUndang Perpajakan sebagai informasi bagi wajib pajak dalam menjalankan kewajiban perpajakan. Perusahaan sebagai wajib pajak dapat memanfaatkan Undang-Undang Perpajakan untuk meminimalisasi jumlah pajak terutang (Carolina et al., 2014). Cara efisiensi jumlah pajak terutang perusahaan dapat dilakukan dengan pemilihan metode yang tepat dari beberapa metode yang diijinkan Undang-Undang Perpajakan kemudian melihat dampak pemilihan metode tersebut pada laba perusahaan. Efisiensi beban pajak melalui perencanaan pajak menjadi perhatian perusahaan karena memberikan keuntungan secara marginal bagi perusahaan guna meningkatkan arus kas, sehingga kas dapat digunakan untuk investasi pada aktivitas yang lain (Nurfauzi dan Firmansyah, 2018).

Perencanaan pajak dipandang sebagai strategi yang menguntungkan bagi nilai pemegang saham karena meminimalkan pembayaran pajak pada pihak lain di luar perusahaan (Bae, 2017; Sugiyanto \& Fitria, 2020). Pada umumnya keputusan perusahaan memiliki implikasi terhadap pajak yang selanjutnya memiliki implikasi terhadap keputusan perusahaan sehingga perusahaan wajib mempertimbangkan beban pajak ketika merancang strategi perusahaan (Delgado et al., 2012).

Menurut Undang-Undang Pajak Penghasilan 36 Tahun 2008 pasal 10 ayat 6, terdapat dua metode yang dapat digunakan oleh wajib pajak dalam menilai persediaan barang dan pemakaian persediaan untuk menghitung harga pokok penjualannya yaitu mendahulukan persediaan yang diperoleh pertama (First In First Out-FIFO) dan merata-ratakan nilai persediaan (weighted average). Masing-masing metode ini memiliki kelebihan dan kekurangan masing-masing. Ketika wajib pajak telah memilih salah satu metode di atas dalam menilai persediaannya maka wajib pajak tersebut harus konsisten dengan pilihannya.

Level persediaan merupakan bagian dari investasi perusahaan yang memiliki dampak terhadap harga penjualan, kualitas, permintaan konsumen, dan waktu tunggu. Pada sisi yang lain, level persediaan memiliki dampak terhadap kemampuan perusahaan untuk 
menghasilkan kas saat ini dan masa yang akan datang (Nurhayati et al., 2019; Sugeng et al., 2020). Persediaan merupakan salah satu aset lancar signifikan bagi perusahaan pada umumnya terutama perusahaan dagang, manufaktur, pertanian, kehutanan, pertambangan kontraktor bangunan, dan penjual jasa tertentu. Hal ini menyebabkan akuntansi untuk persediaan menjadi suatu masalah penting bagi perusahaan-perusahaan tersebut khususnya dalam hal penghitungan harga pokok penjualan (Saerang \& Pontoh, 2019; Pontoh \& Budiarso, 2020).

Persediaan secara umum dimiliki dan digunakan oleh perusahaan untuk dijual, untuk operasi bisnis normal atau barang yang akan digunakan atau dikonsumsi dalam membuat barang yang akan dijual. Untuk mengelola persediaan agar dapat terorganisir dan terkontrol dengan baik maka perlu adanya metode untuk perhitungan persediaan dan dari segi perencanaan pajak. Perhitungan persediaan dapat menunjang efisiensi pajak perusahaan dengan dua metode yang diperkenankan dalam perpajakan di Indonesia yaitu metode FIFO dan metode weighted average.

\section{TINJAUAN PUSTAKA}

Salah satu cara efisiensi beban pajak secara legal dengan melakukan rekayasa usaha dan transaksi wajib pajak adalah menerapkan perencanaan pajak (Sugeng, 2011). Perencanaan pajak merupakan bagian dari manajemen pajak dengan mengikuti peraturan perpajakan yang berlaku dan menentukan tindakan penghematan pajak yang akan diimplementasikan perusahaan. Tujuan perencanaan pajak agar beban pajak dapat diminimalisasi dengan memanfaatkan peraturan perpajakan dapat digolongkan pada tax avoidance (Suandy, 2011:6-7).

Persediaan pada umumnya merupakan salah satu jenis aktiva lancar yang jumlahnya cukup besar dalam suatu perusahaan. Hal ini mudah dipahami karena persediaan merupakan faktor penting dalam menentukan kelancaran operasi perusahaan. Persediaan merupakan bentuk investasi dimana keuntungan (laba) bisa diharapkan melalui penjualan persediaan tersebut di kemudian hari. Oleh sebab itu, pada kebanyakan perusahaan jumlah minimal persediaan harus dipertahankan untuk menjamin kontinuitas dan stabilitas penjualannya. Menurut Shatu (2016:126), persediaan ialah barang-barang yang dibeli oleh perusahaan dengan tujuan untuk dijual kembali dengan tanpa mengubah bentuk dan kualitas barang. Supriyati (2016:23) menjelaskan bahwa persediaan di dalam suatu perusahaan merupakan komponen aset lancar yang memiliki nilai material.

Metode penilaian persediaan sangat beragam, setiap perusahaan berhak untuk menentukan penilaian terhadap persediaan yang dimiliki oleh perusahaan tersebut. PSAK Nomor 14 Revisi 2019 menyatakan bahwa metode penilaian persediaan yang dapat digunakan oleh perusahaan adalah metode FIFO dan metode rata-rata. Hal ini sesuai dengan Undang-Undang Perpajakan dimana hanya memperbolehkan perusahaan menggunakan metode penilaian yaitu metode FIFO dan metode rata-rata.

Metode FIFO merupakan metode yang paling umum digunakan dalam penilaian persediaan. Metode ini juga mengasumsikan bahwa barang-barang digunakan atau dikeluarkan sesuai urutan pembeliannya. Oleh karenanya, barang-barang yang dibeli pertama kali adalah barang pertama yang dijual (dalam perusahaan dagang) atau barang pertama yang digunakan (dalam perusahaan manufaktur) dan barang-barang sisa di tangan (persediaan akhir) diasumsikan untuk biaya akhir (Weygandt et al., 2017:274; Warren et al., 2009:313). Keunggulan metode FIFO adalah laba yang dihasilkan lebih tinggi sehingga performa perusahaan akan terlihat lebih baik dan pengukuran stok akhir lebih stabil karena menggunakan ongkos barang yang dibeli terlebih dahulu. Adapun kelemahan dari metode FIFO adalah dikarenakan laba yang dihasilkan lebih tinggi maka jumlah pajak yang harus dibayarkan akan tinggi. 
Metode rata-rata mengasumsikan bahwa barang-barang yang akan digunakan atau dijual akan dibebani harga pokok secara rata-rata. Perhitungan harga pokok rata-rata dilakukan dengan cara membagi jumlah harga perolehan dengan kuantitasnya. Dengan demikian harga pokok barang terjual diperoleh dengan mengalihkan jumlah unit terjual dengan harga rata-rata dan barang yang masih belum terjual atau persediaan akhir dihitung dari jumlah persediaan dikalikan terhadap harga rata-rata tersebut. Cara ini mengurangi dampak dari fluktuasi harga. Keterbatasan dalam metode rata-rata adalah nilai persediaan secara terus menerus mengandung pengaruh dari kos paling awal dan nilai-nilai tersebut bisa mempunyai lag yang signifikan di belakang current price dalam periode yang mengalami perubahan harga yang cepat, naik atau turun (Setiyanto, 2012).

Penggunaan metode rata-rata ini tidak terlalu berpengaruh dalam perhitungan persediaan akhir, harga pokok penjualan dan laba kotor seperti halnya metode FIFO. Tetapi metode rata-rata membuat perusahaan harus menghitung harga rata-rata setiap melakukan pembelian baru. Dalam pelaksanaannya, metode rata-rata lebih praktis menghasilkan laba yang lebih kecil maka pajak akan lebih murah (rendah) dan nilai stok akhir lebih kecil. Akan tetapi, laba yang kecil akan terlihat kurang baik saat evaluasi oleh para pemegang saham.

Terdapat beberapa perusahaan yang memilih metode rata-rata karena lebih mudah (praktis) dan pajak yang harus dibayarkan lebih sedikit dibandingkan FIFO. Tetapi, dalam penggunaan metode ini harus berhati-hati karena jika salah pada pembelian maka nantinya akan berpengaruh ke harga pokok penjualan dan akhirnya akan berpengaruh pada laba/rugi usaha. Perusahaan yang memilih metode FIFO sebagai metode penilaian persediaan cenderung disebabkan investor ingin melihat bahwa perusahaannya menghasilkan laba yang terus meningkat, agar saham perusahaannya bisa tetap naik namun pajak yang dibayarkan lebih mahal. Berdasarkan pertimbangan tersebut, metode penilaian persediaan perlu dipertimbangkan guna menyesuaikan kondisi, kebijakan, visi, misi, dan tujuan perusahaan.

\section{METODE DAN TEKNIK PENERAPAN IPTKES}

\subsection{Metode penerapan ipteks}

Penerapan ipteks ini berbentuk perhitungan metode persediaan yang diperkenankan perpajakan Indonesia yaitu dengan menggunakan metode FIFO dan metode rata-rata.

\subsection{Teknik penerapan ipteks}

Teknik yang dipilih dalam penerapan ipteks ini adalah menghitung persediaan dengan menggunakan metode FIFO dan metode rata-rata sebagai berikut.

Harga Pokok Penjualan (FIFO) = Saldo awal persediaan (unit $x$ harga) + Pembelian (unit $x$ harga)

Harga Pokok Penjualan (rata-rata) = Saldo awal persediaan (unit $x$ harga) + Pembelian (unit $x$ harga $)=$ Total : Jumlah Unit

\section{PEMBAHASAN}

\subsection{Gambaran Objek Penerapan Ipteks}

Objek penerapan ipteks adalah perusahaan dagang yang menyajikan saldo persediaan beserta harga pokok penjualan yang disajikan dalam laporan laba rugi dengan menggunakan metode FIFO dan metode rata-rata.

\subsection{Pembahasan}

Perpajakan mengijinkan pengakuan nilai persediaan dalam perusahaan berdasarkan dua jenis metode persediaan yaitu metode FIFO dan metode rata-rata. Tabel 1 menyajikan data perusahaan $\mathrm{X}$ guna perbandingan Harga Pokok Penjualan menurut metode FIFO dan metode rata-rata. 
Tabel 1. Data perusahaan $X$ pada tahun 2018

\begin{tabular}{llcr} 
& Unit & Harga & Total \\
\hline Saldo Awal Kas & & & Rp. 7.000 .000 \\
Saldo Awal Laba Ditahan & & & Rp. 10.000 .000 \\
Saldo Awal Persediaan & Rp. 4000 & Rp. 3000 & Rp. 12.000 .000 \\
Pembelian & Rp. 6000 & Rp. 4000 & Rp. 24.000 .000 \\
Penjualan & Rp. 5000 & Rp. 12.000 & Rp. 60.000 .000 \\
Beban Operasi & & & Rp. 10.000 .000 \\
Pajak & & & $30 \%$ \\
\hline
\end{tabular}

Berdasarkan hasil perhitungan pada Tabel 2, terlihat bahwa harga pokok penjualan dengan menggunakan metode FIFO lebih kecil dibandingkan dengan metode rata-rata. Berdasarkan konsep yang telah diuraikan sebelumnya, keunggulan metode FIFO adalah laba yang dihasilkan lebih tinggi sehingga performa perusahaan akan terlihat lebih baik dan pengukuran persediaan akhir lebih tetap dikarenakan menggunakan ongkos barang yang dibeli terlebih dahulu. Adapun kelemahan dari metode FIFO adalah laba yang dihasilkan lebih tinggi sehingga jumlah pajak yang harus dibayarkan akan tinggi. Sebaliknya, metode rata-rata lebih praktis sehingga menghasilkan laba yang lebih kecil maka pajak akan lebih rendah dan nilai persediaan akhir lebih kecil.

Tabel 2. Perhitungan harga pokok penjualan menggunakan metode FIFO dan rata-rata FIFO

\begin{tabular}{|c|c|c|c|}
\hline & Unit & Harga & Total \\
\hline Penjualan & Rp. 5000 & & \\
\hline Saldo awal persediaan & Rp. 4000 & Rp. 3000 & Rp. 12.000 .000 \\
\hline Pembelian & Rp. 1000 & Rp. 4000 & Rp. 4.000 .000 \\
\hline Harga pokok penjualan & & & Rp. 16.000 .000 \\
\hline \multicolumn{4}{|l|}{ Rata-rata } \\
\hline Saldo awal persediaan & 4000 & Rp. 3000 & Rp. 12.000 .000 \\
\hline Pembelian & Rp. $\quad 6000$ & Rp. 4000 & Rp. 24.000 .000 \\
\hline Total & Rp. 10.000 & & Rp. 36.000 .000 \\
\hline Biaya per unit & & & 3.600 \\
\hline Harga pokok penjualan & 5000 & Rp. 3.600 & Rp. 18.000 .000 \\
\hline
\end{tabular}

Tabel 3 menunjukkan bahwa perhitungan persediaan dengan menggunakan metode FIFO akan menghasilkan laba bersih lebih besar dibandingkan dengan perhitungan menggunakan metode rata-rata. Namun jika dilihat dari segi efisiensi pajak, akan lebih tepat jika menggunakan metode rata-rata dibanding metode FIFO dimana hal ini terlihat pada beban pajak atas persediaan yang menggunakan metode rata-rata lebih kecil dibandingkan dengan beban pajak dengan menggunakan metode FIFO.

Tabel 3. Perhitungan laba bersih menggunakan metode FIFO dan rata-rata

\begin{tabular}{lrr}
\hline & Rata-rata & FIFO \\
\hline Penjualan & Rp. 60.000 .000 & Rp. 60.000 .000 \\
Harga Pokok Penjualan & - Rp. 18.000 .000 & - Rp. 16.000 .000 \\
Margin Laba & Rp. 42.000 .000 & Rp. 44.000 .000 \\
Beban Operasi & - Rp. 10.000 .000 & - Rp. 10.000 .000 \\
Laba Sebelum Pajak & Rp. 32.000 .000 & Rp. 34.000 .000 \\
Beban Pajak & Rp. 9.600 .000 & Rp. 10.200 .000 \\
Laba Bersih & Rp. 22.400.000 & Rp. 23.800.000 \\
\hline
\end{tabular}


Tabel 4 menunjukkan bahwa pengunaan metode FIFO akan menghasilkan harga pokok penjualan yang lebih kecil dibandingkan metode rata-rata sehingga laba bersih perusahaan akan menjadi lebih besar dan beban pajak yang harus ditanggung wajib pajak juga lebih besar. Penggunaan metode rata-rata akan menghasilkan margin laba yang lebih kecil sehingga untuk efisensi beban pajak lebih efektif menggunakan metode rata-rata dibandingkan metode FIFO. Dengan kata lain, semakin kecil margin laba yang diperoleh maka semakin kecil jumlah beban pajak yang harus dibayarkan.

Tabel 4. Perbandingan Metode FIFO dan rata-rata

\begin{tabular}{llllll}
\hline & HPP & Margin Laba & \multicolumn{1}{c}{ Pajak } & Laba Bersih & \multicolumn{1}{c}{ Laba Ditahan } \\
\hline Average & Rp. 18.000 .000 & Rp. 42.000.000 & Rp. 9.600 .000 & Rp. 22.400.000 & Rp. 32.400 .000 \\
FIFO & Rp. 16.000 .000 & Rp. 44.000.000 & Rp. 10.200.000 & Rp. 23.800.000 & Rp. 33.800.000 \\
\hline
\end{tabular}

\section{KESIMPULAN DAN SARAN}

\subsection{Kesimpulan}

Terdapat dua metode yang dapat digunakan oleh wajib pajak dalam menilai persediaan barang dan pemakaian persediaan untuk menghitung harga pokok penjualannya yaitu metode FIFO dan metode rata-rata. Pengunaan metode FIFO akan menghasilkan harga pokok penjualan yang lebih kecil dibandingkan metode rata-rata sehingga laba bersih perusahaan akan menjadi lebih besar dan beban pajak yang harus ditanggung wajib pajak juga lebih besar. Sebaliknya, penggunaan metode rata-rata akan menghasilkan margin laba yang lebih kecil sehingga untuk efisensi beban pajak lebih efektif menggunakan metode ratarata dibandingkan metode FIFO.

\subsection{Saran}

Kajian ini menyarankan agar perusahaan selaku wajib pajak badan sebaiknya melakukan beberapa penelitian dalam rangka perencanaan pajak untuk penetapan metode persediaan apa yang paling efektif dan efisien untuk digunakan secara konsisten dan tetap taat menunaikan kewajibannya dalam melaporkan dan membayar pajak secara legal dan sesuai dengan peraturan perundang-undangan pajak yang berlaku.

\section{DAFTAR PUSTAKA}

Bae, S. H. (2017). The association between corporate tax avoidance and audit efforts: Evidence from Korea. The Journal of Applied Business Research, 33(1). 153-172. https://doi.org/10.19030/jabr.v33i1.9887

Delgado, F. J., Rodríguez, E. F., \& Arias, A. M. (2012). Size and other Determinants of Corporate Effective Tax Rates in US Listed Companies. International Research Journal of Finance and Economics, 98. 160-165. http://www.internationalresearchjournaloffinanceandeconomics.com/ISSUES/IRJFE Issue $98 . h$ tm

Carolina, V., Natalia, M., \& Debbianita. (2014). Karakteristik eksekutif terhadap tax avoidance dengan leverage sebagai variabel intervening. Jurnal Keuangan dan Perbankan, 18(3). 409-419. http://jurnal.unmer.ac.id/index.php/jkdp/article/view/819

Nurhayati, Susetyo, D., \& Fuadah, L. L. (2019). The effect of financial policy on tax aggressiveness for manufacturing companies listed at Indonesia Stock Exchange. Modern Economics, 13. 180-186. https://doi.org/10.31521/modecon.V13(2019)-28

Nurfauzi, R., \& Firmansyah, A. (2018). Managerial ability, management compensation, bankruptcy risk, and tax aggressiveness. Media Riset Akuntansi, Auditing \& Informasi, 18(1). 75-100. http://dx.doi.org/10.25105/mraai.v18i1.2775 
Pontoh, W., \& Budiarso, N. S. (2020). Ipteks sistem informasi sederhana atas manajemen persediaan pedagang ritel mikro, kecil, dan menengah. Abdimas Unwahas, 5(1), 8-20. https://publikasiilmiah.unwahas.ac.id/index.php/ABD/article/view/3330

Republik Indonesia. (2008). Undang-Undang Nomor 36 Tahun 2008 Pasal 10 tentang Pajak Penghasilan. Jakarta.

Saerang, D., \& Pontoh, W. (2019). Ipteks sistem persediaan dalam penentuan harga pokok penjualan bagi usaha kecil menengah di Kecamatan Malalayang I Barat Kota Manado. Jurnal Ipteks Akuntansi Bagi Masyarakat, 3(2), 35-39. https://doi.org/10.32400/jiam.3.2.2019.24005

Suandy, E. (2011). Perencanaan Pajak. Jakarta: Salemba Empat

Setiyanto, K. B. (2012). Analisis faktor-faktor yang berpengaruh terhadap pemilihan metode akuntansi persediaan (Studi kasus pada perusahaan dagang dan manufaktur yang terdaftar di BEI Tahun 2008-2010). Skripsi. Fakultas Ekonomika dan Bisnis Universitas Diponegoro. http://eprints.undip.ac.id/35656/

Shatu, Y. P. (2016). Kuasai detail akuntansi laba dan rugi. Pustaka Ilmu Semesta

Standar Akuntansi Keuangan. (2019). Pernyataan Standar Akuntansi Keuangan Nomor 14 Tentang Persediaan. Jakarta.

Sugeng, Prasetyo, E., \& Zaman, B. (2020). Does capital intensity, inventory intensity, firm size, firm risk, and political connections affect tax aggressiveness? JEMA: Jurnal Ilmiah Bidang Akuntansi dan Manajemen, 17(1). 78-87. http://dx.doi.org/10.31106/jema.v17i1.3609

Sugeng, B. (2011). Pengaruh perencanaan pajak terhadap efisiensi beban pajak penghasilan. Jurnal Riset Akuntansi dan Bisnis, 11(2). 122-139. http://jurnal.umsu.ac.id/index.php/akuntan/article/view/406

Sugiyanto, \& Fitria, J. R. (2020). Effect of CSR and leverage to tax aggressiveness with managerial ownership as moderating. Proceedings international seminar on $\begin{array}{llr}\text { accounting } & \text { society. } & \text { 58-65. }\end{array}$ http://openjournal.unpam.ac.id/index.php/PISA/issue/view/582/showToc

Warren, C. S., Reeve, J. M., \& Duchac, J. E. (2009). Accounting. 23e. USA: South-Western, Cengage Learning

Weygandt, J. J., Kimmel, P. D., \& D. E. Kieso. (2017). Financial Accounting. Tenth edition. United States: John Wiley \& Sons, Inc. 